\title{
Silicon as an attenuator of drought stress in plants of Oryza sativa L. treated with dietholate
}

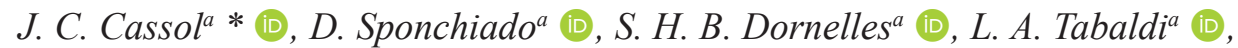 \\ E. P. M. Barreto ${ }^{a}$ (D) M. Pivetta ${ }^{a}$ (D) and S. J. Lopes ${ }^{a}$ \\ ${ }^{a}$ Universidade Federal de Santa Maria, Programa de Pós-graduação em Agrobiologia, Centro de Ciências Naturais e \\ Exatas, Santa Maria, RS, Brasil \\ *e-mail: jessicacassol@agronoma.eng.br
}

Received: March 12, 2020 - Accepted: June 06, 2020

(With 3 figures)

\begin{abstract}
Silicon ( $\mathrm{Si}$ ) is an element that can improve the growth and development of rice plants in water-deficient environments because it is an enzymatic stimulant, signaling for production of antioxidant compounds. Therefore, the aim of this study was to examine the relationship between water deficiency and the effect of Si on two rice cultivars whose seeds were treated with dietholate. The experimental design was fully randomized with three replicates, and treatments were organized in a $3 \times 2 \times 2 \times 4$ factorial arrangement: three water soil conditions $(50 \%$ and $100 \%$ of soil water retention capacity (WRC) and complete submergence in a water blade of $5.0 \mathrm{~cm}$ ); two cultivars (IRGA 424 RI and Guri INTA CL); two sources of Si (sodium metasilicate and potassium metasilicate); and four rates of Si $\left(0 ; 4.0 ; 8.0\right.$ and $\left.16 \mathrm{~g} \mathrm{~L}^{-1}\right)$. Chlorophyll $a$ and $b$, leaf area and shoot and root dry weight increased at higher rates of Si under the three soil water regimes. There was an increase in superoxide dismutase and guaiacol peroxidase enzyme activity in the cultivars at higher rates of Si, reducing lipid peroxidation caused by water deficiency. Therefore, Si did indeed attenuate water deficiency stress in rice plants emerging from seeds treated with dietholate.
\end{abstract}

Keywords: water deficiency, rice, lipid peroxidation.

\section{Silício como atenuador de estresse hídrico em plantas de Oryza sativa L. tratadas com dietholate}

\section{Resumo}

O silício ( $\mathrm{Si}$ ) é um elemento que pode proporcionar melhor crescimento e desenvolvimento às plantas de arroz cultivadas em ambientes com deficiência hídrica, por ser um estimulador enzimático, promovendo sinalização para produção de compostos antioxidantes. Assim, o objetivo deste trabalho foi estudar a relação entre deficiência hídrica e o efeito do Si em duas cultivares de arroz tratadas com dietholate. O delineamento experimental utilizado foi inteiramente casualizado, com três repetições e os tratamentos arranjados em esquema fatorial $3 \times 2 \times 2 \times 4$, sendo os fatores: três condições hídricas do solo $(50 \%, 100 \%$ da capacidade de retenção de água no solo (CRA) e lâmina d'água de 5,0 cm), duas cultivares (IRGA 424 RI e Guri INTA CL), duas fontes de Si (metassilicato de sódio e metassilicato de potássio) e quatro doses de $\mathrm{Si}\left(0 ; 4,0 ; 8,0\right.$ e $\left.16 \mathrm{~g} \mathrm{~L}^{-1}\right)$. O índice de clorofila $a$ e $b$, a área foliar e o teor de massa seca da parte aérea e raiz aumentaram com o aumento das doses de Si nas três condições hídricas do solo. Houve um aumento na atividade das enzimas superóxido dismutase e guaiacol peroxidase nas cultivares estudadas à medida que as doses de Si aumentaram, diminuindo a peroxidação de lipídios, causada pela restrição hídrica. Portanto, o Si atenua o estresse por déficit hídrico em plantas de arroz emergentes de sementes tratadas com dietholate.

Palavras-chave: déficit hídrico, arroz, peroxidação de lipídeos.

\section{Introduction}

Rice (Oryza sativa L.) is one of the most consumed cereals in the world and is a basic human food. Average production in Brazil reached 11.6 million metric tons over the last five years. The state of Rio Grande do Sul is the biggest Brazilian producer, with average production of 8,000 metric tons over this period (CONAB, 2019).
Weeds are considered the main factor limiting rice production (Antigua et al., 1990), and clomazone, Gamit trademark, is one of the most widely used herbicides, inhibiting carotenoid synthesis and impairing photosynthesis. Clomazone is tolerated by the rice crop up to the rates specified, depending on the soil type (Sanchotene et al., 
2010). However, to control the main grasses competing with the rice, higher rates are usually applied during the crop cycle and can be phytotoxic, impairing post-germination seedling growth and tiller production (Karam et al., 2003).

For this reason, dietholate, Permit trademark, is widely used to protect seeds, seeking to reduce the phytotoxic effects of clomazone on seedlings when it is applied at a rate above the level tolerated by the crop (Ferhatoglu et al., 2005). Dietholate is an organophosphate compound that inhibits cytochrome P-450 mono-oxygenase, the agent that hydroxylates clomazone inside the cell cytoplasm, rendering it toxic to the rice plant (Sanchotene et al., 2010). However, in plants this enzyme detoxifies certain compounds (Yun et al., 2005) and when inhibited by the dietholate, the activation of antioxidant enzymes such as superoxide dismutase (SOD), peroxidases (POD) and catalase (CAT) can also be inhibited. These antioxidant enzymes play an important role in removing excess of reactive oxygen species (ROS) from the cell, produced during periods of biotic and abiotic stresses and impairing photosystems and lipid peroxidation, rupturing membranes and causing cell leakage and other effects, resulting in cell collapse and death (Silva et al., 2019).

Research has shown that these deleterious effects caused by dietholate can be triggered by water deficiency (Mauad et al., 2011). To reduce these effects, biostimulants containing some essential minerals and phytohormones have been used (Inoue et al., 2012). The success of these biostimulants, recommended as possible regulators of metabolic activity in plants, is usually due to mineral elements such as Si (Mauad et al., 2011). Which is an enzymatic stimulant (Taiz et al., 2017). And can affect plant growth and development by initiating signaling for production of antioxidant compound and osmoprotectants, such as proline and glycine betaine (Etesami and Jeong, 2017). Glycine betaine protects thylakoid membranes, maintaining photochemical efficiency in photosynthesis (Ashraf and Foolad, 2007). Proline acts to stabilize proteins and protects membranes against the deleterious effects of ROS (Sharma and Dubey, 2005).

There are no conclusive studies on the effectiveness of biosimulants in mitigating the stresses caused by the use of dietholate, neither if they are correlated or not with water deficiency. The aim of this study was to evaluate the possible effects of $\mathrm{Si}$ in attenuating water deficiency stress in plant grown from rice seeds treated with dietholate.

\section{Material and Methods}

The experiment was conducted in the greenhouse (6 x 20 m, headroom 5 m) from February to April 2018. The experimental design was fully randomized with three replicates, organized in a $3 \times 2 \times 2 \times 4$ factorial arrangement: three soil water regimes $(50 \%$ and $100 \%$ of soil water retention capacity (WRC) and a $5 \mathrm{~cm}$ water blade); two cultivars (IRGA 424 RI and Guri INTA CL); two sources of $\mathrm{Si}$ a) sodium metasilicate (composition: $\mathrm{Na}_{2} \mathrm{O} \cong 28 \%$; $\mathrm{SiO}_{2} \cong 27 \%$; $\mathrm{Fe} \cong 0.02 \%$ ), and b) potassium metasilicate (composition: $\mathrm{N} \cong 3 \% ; \mathrm{P}_{2} \mathrm{O}_{5} \cong 2 \% ; \mathrm{K}_{2} \mathrm{O} \cong 15 \% ; \mathrm{SiO}_{2} \cong 25 \%$ ); and four rates of $\mathrm{Si}$ applied to the seed in-furrow $(0 ; 4.0$; 8.0 and $\left.16 \mathrm{~g} \mathrm{~L}^{-1}\right)$.

Each experimental unit consisted of a pot containing $500 \mathrm{~g}$ dystrophic sandy red-yellow argisol. The basic fertilization with NPK macro and micronutrients was applied prior to sowing, based on the results of the chemical soil analysis, using a ROLAS recommendation table (Official Soil Analysis Laboratory Network) for irrigated rice. All treatments received the same basic fertilization condition. Ten seeds treated with dietholate seed protector (Permit Star $\left.{ }^{\circledR}\right)$ at a rate of $6 \mathrm{~mL}$ per $\mathrm{kg}$ seed were sown in each pot at a depth of two centimeters, and after emergence the six most similar seedlings in each pot were retained.

The method described in Spatt (2018) was used to maintain water conditions at $50 \%$ and $100 \%$ of soil water retention capacity (WRC) and for daily irrigation. Treatments related to soil water regimes were begun 15 days after sowing, simulating water ingress conditions in an irrigated rice crop. Evaluations of rice plant physiological and morphological variables were carried out when the plants were in vegetative stage V10.

Shoot lipid peroxidation was evaluated using the method described by El-Moshaty et al. (1993); guaiacol peroxidase (POD) enzyme activity was determined using the method described in Zeraik et al. (2008); and the spectrophotometric method was used to determine superoxide dismutase (SOD) activity according to Giannopolitis and Ries (1977).

Chlorophyll $a$ and $b$ were evaluated using a chlorophyll meter (ClorofiLOG ${ }^{\circledR}$, Falker) on the middle third of the fourth leaf of three plants per treatment, and leaf area $\left(\mathrm{cm}^{2}\right)$ was measured using an AM350 meter (ADC BioScientific). To evaluate plant dry weight, three plants were removed from each pot, placed in a porous paper bag and dried in a forced air oven at $65^{\circ} \mathrm{C}$ until a constant dry weight (g) was reached.

Response variables were subjected to analysis of variance, and factors analyzed by the Tukey test at 0.05 error probability, except for the silicon rates that were fitted to polynomial models using Sisvar ${ }^{\circledR} 5.3$ statistical software (Ferreira, 2014)

\section{Results and Discussion}

Shoot and root dry weight variables showed significant interaction for all factors (water regime $\mathrm{x}$ cultivar $\mathrm{x}$ rate of $\mathrm{Si}$ x source of $\mathrm{Si}$ ). Lipid peroxidation showed interaction between water regime $\mathrm{x}$ cultivar $\mathrm{x}$ rate of $\mathrm{Si}$, with no effect for the source of Si in the F-test $(\mathrm{p}<0.05)$. Thus, for this variable regression models and tables were obtained for the means of the two sources. For peroxidase (POD) enzyme activity and leaf area, there was an interaction between the rate of $\mathrm{Si}$ and the soil water regime, with the cultivar and source of Si showing no effect in the F-test $(p<0.05)$. Thus, for these variables, regression models and tables were obtained for the means of the two cultivars and two sources. Chlorophyll $a$ and $b$ showed interactions between the soil water regime $\mathrm{x}$ rate of $\mathrm{Si}$ x source of $\mathrm{Si}$, 
but there was no cultivar effect in the F-test $(p<0.05)$. Thus, regression models and tables were obtained for the means of the two cultivars. For superoxide dismutase (SOD) enzyme activity, there was a significant effect only for the rate of $\mathrm{Si}$, with no effect for the cultivar, source of $\mathrm{Si}$ and soil water regime in the F-test $(\mathrm{p}<0.05)$. Thus, regression models were obtained for the means of the cultivars, sources of $\mathrm{Si}$ and soil water regimes.

In general, the shoot dry weight variable was higher for complete submergence (water blade), which is the ideal condition for the development of rice plants (Ismail et al., 2012). Si showed a positive effect on shoot dry weight under the three soil water regimes, increasing the dry weight of both cultivars (Table 1). Si boosts growth by reinforcing the absorption of mineral nutrients, possibly by a kinetic relationship with the absorption process for some nutrients, improves the absorption of nitrogen, phosphorus and potassium in rice (Lee et al., 2010; Pati et al., 2016; Crooks and Prentice, 2017).

The only statistical difference was for the shoot dry weight variable under the soil water regime of $50 \% \mathrm{WRC}$ and at 8.0 and $16 \mathrm{~g} \mathrm{~L}^{-1}$ sodium metasilicate. The IRGA $424 \mathrm{RI}$ cultivar had a higher mean shoot dry weight than Guri INTA CL. Conversely, under the water blade at a rate of $16 \mathrm{~g} \mathrm{~L}^{-1}$ sodium metasilicate, the Guri INTA CL showed a higher mean shoot dry weight (Table 2).

Regression analysis on the rates of Si showed that, on average, the shoot dry weight of the two cultivars was influenced by the rates of potassium metasilicate. For the IRGA 424 RI cultivar, under all three water regimes (50 and 100\% WRC and the water blade), shoot dry weight increased respectively by 66,120 and $65 \%$ at the higher rate of potassium metasilicate $\left(16 \mathrm{~g} \mathrm{~L}^{-1}\right)$ compared to plants not supplemented with $\mathrm{Si}\left(0 \mathrm{~g} \mathrm{~L}^{-1}\right)$ (Supplementary Material). For the Guri INTA CL cultivar, the water blade did not significantly increase dry weight at the potassium metasilicate rates used (supplementary data). However, at 50 and $100 \%$ WRC, shoot dry weight increased by 144 and $54 \%$ with the addition of $16 \mathrm{~g} \mathrm{~L}^{-1}$ potassium metasilicate compared to plants not supplemented with $\mathrm{Si}\left(0 \mathrm{~g} \mathrm{~L}^{-1}\right)$ (supplementary data). In terms of shoot dry weight for both IRGA 424 RI and Guri INTA CL under all three water regimes (50 and 100\% WRC and water blade), sodium metasilicate at a rate of $16 \mathrm{~g} \mathrm{~L}^{-1}$ increased the respective dry weight by 166,86 and $43 \%$ for the IRGA 424 RI cultivar and 107, 52 and $92 \%$ for the Guri INTA CL cultivar, compared to plants not supplemented with $\mathrm{Si}\left(0 \mathrm{~g} \mathrm{~L}^{-1}\right)$ (supplementary data).

Si positively affected shoot dry weight under all water regimes, and despite the fact that water restriction impaired rice plant growth in terms of some parameters, Si did improve the plant's physiological growth processes, corroborating the work of Lima et al. (2011). Habibi (2014), working on the effects on some physiological characteristics of canola plants (Brassica napus L. cv. Okapi) observed that plants grown under drought stress for 25 days and treated with Si exhibited higher shoot and root dry weight, compared to those not treated with Si under the same drought stress conditions. The exogenous supplementation of Si proves to be beneficial for plants particularly under abiotic stress

Table 1. Comparison of means between sources of $\mathrm{Si}$ and water soil conditions, at dry weight of shoot and root for rice plants, at different Si rates and cultivars. Santa Maria, RS, 2019.

\begin{tabular}{|c|c|c|c|c|c|c|c|c|}
\hline \multirow{3}{*}{$\begin{array}{c}\text { RATES } \\
\text { OF Si }\end{array}$} & \multirow{3}{*}{ CULTIVAR } & \multirow{3}{*}{ SOURCES OF Si } & \multicolumn{6}{|c|}{ WATER SOIL CONDITIONS } \\
\hline & & & \multicolumn{3}{|c|}{ Shoot dry } & \multicolumn{3}{|c|}{ Root dry } \\
\hline & & & $\begin{array}{l}\mathbf{5 0 \%} \\
\text { WRC }\end{array}$ & $\begin{array}{l}100 \% \\
\text { WRC }\end{array}$ & $\begin{array}{l}\text { Water } \\
\text { blade }\end{array}$ & $\begin{array}{l}\mathbf{5 0 \%} \\
\text { WRC }\end{array}$ & $\begin{array}{l}100 \% \\
\text { WRC }\end{array}$ & $\begin{array}{l}\text { Water } \\
\text { blade }\end{array}$ \\
\hline \multirow[t]{2}{*}{$0 \mathrm{~g} \mathrm{~L}^{-1}$} & Guri I & $\begin{array}{l}\text { Potassium metasilicate } \\
\text { Sodium metasilicate }\end{array}$ & $0.26 b^{*}$ & $0.47 \mathrm{~b}$ & $0.69 \mathrm{a}$ & $0.19 \mathrm{~b}$ & $0.22 \mathrm{~b}$ & $0.60 \mathrm{a}$ \\
\hline & IRGA 424RI & $\begin{array}{l}\text { Potassium metasilicate } \\
\text { Sodium metasilicate }\end{array}$ & $0.30 \mathrm{~b}$ & $0.40 \mathrm{~b}$ & $0.67 \mathrm{a}$ & $0.13 \mathrm{a}$ & $0.20 \mathrm{a}$ & $0.24 \mathrm{a}$ \\
\hline \multirow[t]{4}{*}{$4.0 \mathrm{~g} \mathrm{~L}^{-1}$} & Guri INTA CL & Potassium metasilicate & $0.36 \mathrm{Ab}$ & $0.51 \mathrm{Ab}$ & $0.79 \mathrm{Aa}$ & $0.11 \mathrm{Ab}$ & $0.16 \mathrm{Ab}$ & $0.45 \mathrm{Aa}$ \\
\hline & & Sodium metasilicate & $0.46 \mathrm{Ab}$ & $0.61 \mathrm{Ab}$ & $0.9 \mathrm{Aa}$ & $0.27 \mathrm{Ab}$ & $0.30 \mathrm{Ab}$ & $0.59 \mathrm{Aa}$ \\
\hline & IRGA 424RI & Potassium metasilicate & $0.36 \mathrm{Ab}$ & $0.46 \mathrm{Aab}$ & $0.63 \mathrm{Ba}$ & $0.18 \mathrm{Aa}$ & $0.31 \mathrm{Aa}$ & $0.34 \mathrm{Ba}$ \\
\hline & & Sodium metasilicate & $0.39 \mathrm{Ab}$ & $0.46 \mathrm{Ab}$ & $0.83 \mathrm{Aa}$ & $0.17 \mathrm{Ab}$ & $0.34 \mathrm{Ab}$ & $1.18 \mathrm{Aa}$ \\
\hline \multirow[t]{4}{*}{$8.0 \mathrm{~g} \mathrm{~L}^{-1}$} & Guri INTA CL & Potassium metasilicate & $0.43 \mathrm{Ab}$ & $0.58 \mathrm{Aab}$ & $0.76 \mathrm{Aa}$ & $0.13 \mathrm{Ab}$ & $0.29 \mathrm{Ab}$ & $2.60 \mathrm{Aa}$ \\
\hline & & Sodium metasilicate & $0.53 \mathrm{Ab}$ & $0.66 \mathrm{Ab}$ & $0.93 \mathrm{Aa}$ & $0.26 \mathrm{Ab}$ & $0.29 \mathrm{Ab}$ & $1.99 \mathrm{Ba}$ \\
\hline & IRGA 424RI & Potassium metasilicate & $0.44 \mathrm{Ba}$ & $0.53 \mathrm{Aa}$ & $0.65 \mathrm{Aa}$ & $0.21 \mathrm{Ac}$ & $0.41 \mathrm{Ab}$ & $0.68 \mathrm{Ba}$ \\
\hline & & Sodium metasilicate & $0.80 \mathrm{Aa}$ & $0.69 \mathrm{Aa}$ & $0.76 \mathrm{Aa}$ & $0.19 \mathrm{Ab}$ & $0.30 \mathrm{Ab}$ & $1.71 \mathrm{Aa}$ \\
\hline \multirow[t]{5}{*}{$16 \mathrm{~g} \mathrm{~L}^{-1}$} & Guri INTA CL & Potassium metasilicate & $0.61 \mathrm{Ab}$ & $0.71 \mathrm{Aab}$ & $0.89 \mathrm{Ba}$ & $0.16 \mathrm{Ab}$ & $0.29 \mathrm{Ab}$ & $2.22 \mathrm{Aa}$ \\
\hline & & Sodium metasilicate & $0.58 \mathrm{Ab}$ & $0.73 \mathrm{Ab}$ & $1.21 \mathrm{Aa}$ & $0.30 \mathrm{Ab}$ & $0.38 \mathrm{Ab}$ & $2.01 \mathrm{Ba}$ \\
\hline & IRGA 424RI & Potassium metasilicate & $0.50 \mathrm{Bb}$ & $0.84 \mathrm{Aa}$ & $1.04 \mathrm{Aa}$ & $0.32 \mathrm{Ab}$ & $0.50 \mathrm{Ab}$ & $1.03 \mathrm{Ba}$ \\
\hline & & Sodium metasilicate & $0.85 \mathrm{Aa}$ & $0.82 \mathrm{Aa}$ & $0.96 \mathrm{Aa}$ & $0.24 \mathrm{Ab}$ & $0.24 \mathrm{Bb}$ & $2.14 \mathrm{Aa}$ \\
\hline & & & \multicolumn{3}{|c|}{$\mathrm{CV}(\%)=17.73$} & \multicolumn{3}{|c|}{$\mathrm{CV}(\%)=18.25$} \\
\hline
\end{tabular}

*Means not followed by the same uppercase letter in the column were statistically different for different Si sources and the same lowercase letter on the row differed for soil water regimes in the Tukey test $(\mathrm{p} \leq 0.05)$. WRC: Soil Water Retention Capacity. 
Table 2. Comparison of means between cultivars, at dry weight of shoot and root for rice plants, at different sources and Si rates and water soil conditions. Santa Maria, RS, 2019.

\begin{tabular}{|c|c|c|c|c|c|c|c|c|}
\hline \multirow{3}{*}{$\begin{array}{c}\text { RATES } \\
\text { OF Si }\end{array}$} & \multirow{3}{*}{$\begin{array}{c}\text { SOURCES } \\
\text { OF Si }\end{array}$} & \multirow{3}{*}{ CULTIVAR } & \multicolumn{6}{|c|}{ WATER SOIL CONDITIONS } \\
\hline & & & \multicolumn{3}{|c|}{ Shoot dry } & \multicolumn{3}{|c|}{ Root dry } \\
\hline & & & $\begin{array}{c}50 \% \\
\text { WRC }\end{array}$ & $\begin{array}{l}100 \% \\
\text { WRC }\end{array}$ & $\begin{array}{l}\text { Water } \\
\text { blade }\end{array}$ & $\begin{array}{l}50 \% \\
\text { WRC }\end{array}$ & $\begin{array}{l}100 \% \\
\text { WRC }\end{array}$ & $\begin{array}{l}\text { Water } \\
\text { blade }\end{array}$ \\
\hline \multirow[t]{4}{*}{$0 \mathrm{~g} \mathrm{~L}^{-1}$} & \multirow{2}{*}{$\begin{array}{l}\text { Potassium } \\
\text { metasilicate }\end{array}$} & Guri INTA CL & $0.25 \mathrm{~A}^{*}$ & $0.46 \mathrm{~A}$ & $0.76 \mathrm{~A}$ & $0.14 \mathrm{~A}$ & $0.18 \mathrm{~A}$ & $0.38 \mathrm{~A}$ \\
\hline & & IRGA 424RI & $0.30 \mathrm{~A}$ & $0.40 \mathrm{~A}$ & $0.63 \mathrm{~A}$ & $0.11 \mathrm{~A}$ & $0.12 \mathrm{~A}$ & $0.22 \mathrm{~B}$ \\
\hline & \multirow{2}{*}{$\begin{array}{c}\text { Sodium } \\
\text { metasilicate }\end{array}$} & Guri INTA CL & $0.28 \mathrm{~A}$ & $0.48 \mathrm{~A}$ & $0.63 \mathrm{~A}$ & $0.24 \mathrm{~A}$ & $0.26 \mathrm{~A}$ & $0.81 \mathrm{~A}$ \\
\hline & & IRGA 424RI & $0.30 \mathrm{~A}$ & $0.43 \mathrm{~A}$ & $0.70 \mathrm{~A}$ & $0.16 \mathrm{~A}$ & $0.27 \mathrm{~A}$ & $0.26 \mathrm{~B}$ \\
\hline \multirow[t]{4}{*}{$4.0 \mathrm{~g} \mathrm{~L}^{-1}$} & \multirow{2}{*}{$\begin{array}{l}\text { Potassium } \\
\text { metasilicate }\end{array}$} & Guri INTA CL & $0.37 \mathrm{~A}$ & $0.51 \mathrm{~A}$ & $0.79 \mathrm{~A}$ & $0.11 \mathrm{~A}$ & $0.16 \mathrm{~A}$ & $0.59 \mathrm{~B}$ \\
\hline & & IRGA 424RI & $0.36 \mathrm{~A}$ & $0.46 \mathrm{~A}$ & $0.63 \mathrm{~A}$ & $0.18 \mathrm{~A}$ & $0.31 \mathrm{~A}$ & $1.19 \mathrm{~A}$ \\
\hline & \multirow{2}{*}{$\begin{array}{c}\text { Sodium } \\
\text { metasilicate }\end{array}$} & Guri INTA CL & $0.46 \mathrm{~A}$ & $0.61 \mathrm{~A}$ & $0.83 \mathrm{~A}$ & $0.27 \mathrm{~A}$ & $0.31 \mathrm{~A}$ & $0.45 \mathrm{~A}$ \\
\hline & & IRGA 424RI & $0.39 \mathrm{~A}$ & $0.46 \mathrm{~A}$ & $0.90 \mathrm{~A}$ & $0.18 \mathrm{~A}$ & $0.34 \mathrm{~A}$ & $0.34 \mathrm{~A}$ \\
\hline \multirow[t]{4}{*}{$8.0 \mathrm{~g} \mathrm{~L}^{-1}$} & \multirow{2}{*}{$\begin{array}{l}\text { Potassium } \\
\text { metasilicate }\end{array}$} & Guri INTA CL & $0.43 \mathrm{~A}$ & $0.58 \mathrm{~A}$ & $0.76 \mathrm{~A}$ & $0.13 \mathrm{~A}$ & $0.29 \mathrm{~A}$ & $1.99 \mathrm{~A}$ \\
\hline & & IRGA 424RI & $0.44 \mathrm{~A}$ & $0.53 \mathrm{~A}$ & $0.65 \mathrm{~A}$ & $0.21 \mathrm{~A}$ & $0.41 \mathrm{~A}$ & $1.71 \mathrm{~B}$ \\
\hline & \multirow{2}{*}{$\begin{array}{c}\text { Sodium } \\
\text { metasilicate }\end{array}$} & Guri INTA CL & $0.53 \mathrm{~B}$ & $0.66 \mathrm{~A}$ & $0.93 \mathrm{~A}$ & $0.26 \mathrm{~A}$ & $0.30 \mathrm{~A}$ & $2.60 \mathrm{~A}$ \\
\hline & & IRGA 424RI & $0.80 \mathrm{~A}$ & $0.69 \mathrm{~A}$ & $0.76 \mathrm{~A}$ & $0.19 \mathrm{~A}$ & $0.30 \mathrm{~A}$ & $0.68 \mathrm{~B}$ \\
\hline \multirow[t]{5}{*}{$16.0 \mathrm{~g} \mathrm{~L}^{-1}$} & \multirow{2}{*}{$\begin{array}{l}\text { Potassium } \\
\text { metasilicate }\end{array}$} & Guri INTA CL & $0.61 \mathrm{~A}$ & $0.71 \mathrm{~A}$ & $0.89 \mathrm{~A}$ & $0.16 \mathrm{~A}$ & $0.29 \mathrm{~B}$ & $2.01 \mathrm{~A}$ \\
\hline & & IRGA 424RI & $0.50 \mathrm{~A}$ & $0.84 \mathrm{~A}$ & $1.04 \mathrm{~A}$ & $0.32 \mathrm{~A}$ & $0.50 \mathrm{~A}$ & $2.14 \mathrm{~A}$ \\
\hline & \multirow{3}{*}{$\begin{array}{c}\text { Sodium } \\
\text { metasilicate }\end{array}$} & Guri INTA CL & $0.58 \mathrm{~B}$ & $0.73 \mathrm{~A}$ & $1.21 \mathrm{~A}$ & $0.30 \mathrm{~A}$ & $0.38 \mathrm{~A}$ & $2.22 \mathrm{~A}$ \\
\hline & & IRGA 424RI & $0.85 \mathrm{~A}$ & $0.82 \mathrm{~A}$ & $0.96 \mathrm{~B}$ & $0.24 \mathrm{~A}$ & $0.25 \mathrm{~A}$ & $1.03 \mathrm{~B}$ \\
\hline & & & \multicolumn{3}{|c|}{$\mathrm{CV}(\%)=17.73$} & \multicolumn{3}{|c|}{$C V(\%)=18.25$} \\
\hline
\end{tabular}

*Means not followed by the same uppercase letter in the column were statistically different between cultivars in the Tukey test $(\mathrm{p} \leq 0.05)$. WRC: Soil Water Retention Capacity.

conditions (Manivannan and Ahn, 2017). Silicon nutrition resulted in the improvement of growth and development (Eneji et al., 2008; Soundararajan et al., 2014; Zhang et al., 2015), increase in yield (Epstein, 1999), abiotic stress tolerance (Ma, 2004; Zhu et al., 2004; Liang et al., 2007; Muneer et al., 2014), and management of macro and micro nutrients (Tripathi et al., 2014).

In general, there were no differences in root dry weight in relation to the source of $\mathrm{Si}$ under soil water regimes of 50 and $100 \%$ WRC for the two sources of Si. Under the water blade, sodium metasilicate resulted in higher root dry weight in the IRGA 424 RI cultivar, whereas the Guri INTA CL cultivar exhibited higher root dry weight when supplemented with potassium metasilicate (Table 1).

With regard to soil water regimes, it can be seen that under water deficiency ( $50 \%$ WRC), root dry weight dropped significantly compared to the water blade (ideal condition) (Table 1).

Comparing the two cultivars, in general there was a significant different in root dry weight for plants grown under the water blade. Of the eight treatments combined with the water blade, $62 \%$ exhibited higher root dry weight for the Guri INTA CL cultivar compared to the IRGA 424 RI cultivar (Table 2). The absorption and transportation of $\mathrm{Si}$ in plants is a complex process which involves influx and efflux Si transporters belonging to aquaporin family with specific selectivity properties. For instance, the high $\mathrm{Si}$ accumulator like rice consists of low silicon rice 1 (Lsi1) transporter, a nodulin 26-like intrinsic protein (NIP) in roots (Manivannan and Ahn 2017). According to Ma et al.
(2007), genotypic differences in the accumulation of $\mathrm{Si}$ in rice plants could be related to the difference in the expression of $\mathrm{Si}$ transporter genes in the roots.

In the regression analysis on Si rates for the means of root dry weight, it was observed that in the IRGA 424 RI cultivar, increasing the rate of potassium metasilicate resulted in a linear increase in dry weight under the three water regimes ( 50 and $100 \% \mathrm{WRC}$ and water blade), with respective increases of 166,316 and $296 \%$ at the highest rate $\left(16 \mathrm{~g} \mathrm{~L}^{-1}\right)$ compared to plants not supplemented with Si $\left(0 \mathrm{~g} \mathrm{~L}^{-1}\right)$ (supplementary data). In contrast, for the rates of sodium metasilicate, in IRGA $424 \mathrm{RI}$ there was a quadratic relationship under the water blade, peaking at a rate of $12.5 \mathrm{~g} \mathrm{~L}^{-1}$. Under the other two water regimes, there was no significant polynomial (supplementary data). For the Guri INTA CL cultivar at water blade, increasing the rates of both sources of $\mathrm{Si}$ (sodium metasilicate and potassium metasilicate) resulted in a quadratic increase in root dry weight, peaking at 16 and $15 \mathrm{~g} \mathrm{~L}^{-1}$ sodium metasilicate and potassium metasilicate, respectively. The other water regimes did not produce any significant fits in the polynomial models (supplementary data).

This corroborates the work of Faria Junior et al. (2009), who observed an increase in root dry weight in proportion to increases in rates of $\mathrm{Si}$ in the Conai and Curinga cultivars. Hattori et al. (2005) reported that under dry conditions, sorghum plants (Sorghum bicolor (L.) Moench) treated with Si showed improved root growth compared to plants not treated with Si. Sávio et al. (2011) reported that Brachiaria 
brizantha and Panicum máximum responded positively to $\mathrm{Si}$ in terms of dry weight production.

With regard to mean leaf area under the different water regimes, the highest availability of water in the soil (water blade) resulted in higher rice plant leaf area for the two cultivars and sources of $\mathrm{Si}$, regardless of the rate of $\mathrm{Si}$ (Figure 1). Growth in plants is initiated primarily by the multiplication of meristematic cells and the subsequent elongation of these cells, and water plays an important part in cell elongation under the effect of turgor pressure (Woodruff and Meinzer, 2011). That is why drought stress reduces plant growth and impairs crop yield (Boyer, 1982).

In the regression analysis for the effects of $\mathrm{Si}$ rates on leaf area under the three soil water regimes (50 and 100\% WRC and water blade), there was a linear increase in leaf area associated with increased rates of $\mathrm{Si}$, with an increase of $81 \%$ at $50 \% \mathrm{WRC}\left(\mathrm{Y}=03951 \mathrm{x}+6.682 ; \mathrm{R}^{2}=0.932\right), 39 \%$ at $100 \% \mathrm{WRC}\left(\mathrm{Y}=0.4168 \mathrm{x}+17.85 ; \mathrm{R}^{2}=0.949\right)$ and $51 \%$ for the water blade $\left(Y=0.9841 x+31.574 ; R^{2}=0.966\right)$ at the highest Si rate $\left(16 \mathrm{~g} \mathrm{~L}^{-1}\right)$ compared to plants not treated with $\mathrm{Si}\left(0 \mathrm{~g} \mathrm{~L}^{-1}\right)$, showing the beneficial effect of $\mathrm{Si}$, even in cases of water deficiency $(50 \% \mathrm{WRC})$. It is possible that this effect was the result of an increase in the relative moisture content in the leaf brought about by the $\mathrm{Si}$, increasing turgor pressure inside the cells, promoting cell expansion and boosting leaf area, corroborating the results of Kim et al. (2012).

With regard to the means of chlorophyll $a$ and $b$ under the different water regimes and sources of $\mathrm{Si}$, in general the chlorophyll readings were higher in submerged plants (water blade), possibly because of the increased production or lower degradation of pigments. There was no significant difference between the sources of Si for chlorophyll $a$ and $b$ (Table 3 ).

A regression analysis between rates of $\mathrm{Si}$ and chlorophyll $a$ for the potassium metasilicate source showed that the highest rate $\left(16 \mathrm{~g} \mathrm{~L}^{-1}\right)$ resulted in respective linear increments of 26 and $40 \%$ in chlorophyll $a$ in plants grown at $100 \%$ WRC and under the water blade, compared to plants not supplemented with $\mathrm{Si}\left(0 \mathrm{~g} \mathrm{~L}^{-1}\right)$. At 50\% WRC, there was

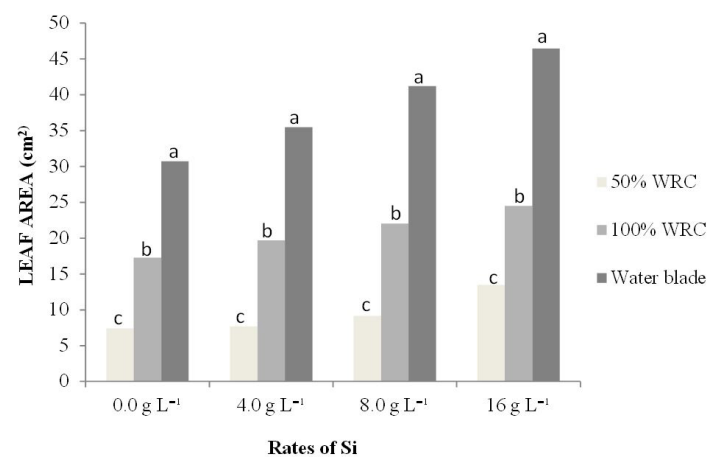

Figure 1. Means for rice plant leaf area at different Si rates for the soil water regime factor. Santa Maria, RS, 2019. * Means not followed by the same letter were statistically different for soil water regimes in the Tukey test $(\mathrm{p} \leq 0.05)$. WRC: soil water retention capacity. a quadratic increase in chlorophyll $a$, peaking at a rate of $13 \mathrm{~g} \mathrm{~L}^{-1}$ potassium metasilicate (Figure 2a). For the sodium metasilicate under water regimes of 50 and $100 \%$ WRC, there were respective increases of 30 and $47 \%$ in chlorophyll $a$ at a rate of $16 \mathrm{~g} \mathrm{~L}^{-1}$ compared to plants not supplemented with $\mathrm{Si}\left(0 \mathrm{~g} \mathrm{~L}^{-1}\right)$. However, under the water blade, there was a quadratic increase peaking at a rate of $13 \mathrm{~g} \mathrm{~L}^{-1}$ sodium metasilicate (Figure $2 \mathrm{~b}$ ).

Table 3. Means for rice plant shoot chlorophyll $a$ and $b$ for different $\mathrm{Si}$ rates and sources for the soil water regime factor. Santa Maria, RS, 2019.

\begin{tabular}{|c|c|c|c|c|}
\hline \multirow{3}{*}{$\begin{array}{c}\text { RATES } \\
\text { OF Si }\end{array}$} & \multirow{3}{*}{$\begin{array}{c}\text { SOURCES } \\
\text { OF Si }\end{array}$} & \multicolumn{3}{|c|}{ WATER SOIL CONDITIONS } \\
\hline & & $\begin{array}{l}\mathbf{5 0 \%} \\
\text { WRC } \\
\end{array}$ & $\begin{array}{l}100 \% \\
\text { WRC } \\
\end{array}$ & $\begin{array}{l}\text { Water } \\
\text { blade } \\
\end{array}$ \\
\hline & & \multicolumn{3}{|c|}{ CHLOROPHYLL $a$} \\
\hline $0 \mathrm{~g} \mathrm{~L}^{-1}$ & $\begin{array}{c}\text { Sodium } \\
\text { metasilicate } \\
\text { Potassium } \\
\text { metasilicate }\end{array}$ & $21.45 \mathrm{a}^{*}$ & $25.9 \mathrm{a}$ & $25.97 \mathrm{a}$ \\
\hline \multirow[t]{2}{*}{$4.0 \mathrm{~g} \mathrm{~L}^{-1}$} & $\begin{array}{c}\text { Sodium } \\
\text { metasilicate }\end{array}$ & $26.68 \mathrm{Ab}$ & $28.91 \mathrm{Ab}$ & $36.25 \mathrm{Aa}$ \\
\hline & $\begin{array}{l}\text { Potassium } \\
\text { metasilicate }\end{array}$ & $30.16 \mathrm{Ab}$ & $29.63 \mathrm{Ab}$ & $38.43 \mathrm{Aa}$ \\
\hline \multirow[t]{2}{*}{$8.0 \mathrm{~g} \mathrm{~L}^{-1}$} & $\begin{array}{c}\text { Sodium } \\
\text { metasilicate }\end{array}$ & $28.13 \mathrm{Bb}$ & $31.68 \mathrm{Ab}$ & $39.15 \mathrm{Aa}$ \\
\hline & $\begin{array}{l}\text { Potassium } \\
\text { metasilicate }\end{array}$ & $32.30 \mathrm{Aab}$ & $30.18 \mathrm{Ab}$ & $38.85 \mathrm{Aa}$ \\
\hline \multirow[t]{4}{*}{$16 \mathrm{~g} \mathrm{~L}^{-1}$} & $\begin{array}{c}\text { Sodium } \\
\text { metasilicate }\end{array}$ & $32.33 \mathrm{Ab}$ & 36.62 Aab & $41.58 \mathrm{Aa}$ \\
\hline & Potassium & $35.00 \mathrm{Ab}$ & $33.95 \mathrm{Ab}$ & 43.61 Aa \\
\hline & & \multicolumn{3}{|c|}{$C V(\%)=16.54$} \\
\hline & & \multicolumn{3}{|c|}{ CHLOROPHYLL $b$} \\
\hline $0 \mathbf{g ~ L}^{-1}$ & $\begin{array}{c}\text { Sodium } \\
\text { metasilicate } \\
\text { Potassium } \\
\text { metasilicate }\end{array}$ & $5.71 \mathrm{~b}$ & $7.58 \mathrm{ab}$ & $8.46 \mathrm{a}$ \\
\hline \multirow[t]{2}{*}{$4.0 \mathrm{~g} \mathrm{~L}^{-1}$} & $\begin{array}{c}\text { Sodium } \\
\text { metasilicate }\end{array}$ & $6.88 \mathrm{Ab}$ & $7.80 \mathrm{Ab}$ & $9.26 \mathrm{Ba}$ \\
\hline & $\begin{array}{l}\text { Potassium } \\
\text { metasilicate }\end{array}$ & $7.93 \mathrm{Ab}$ & $8.05 \mathrm{Ab}$ & $11.06 \mathrm{Aa}$ \\
\hline \multirow[t]{2}{*}{$8.0 \mathrm{~g} \mathrm{~L}^{-1}$} & $\begin{array}{c}\text { Sodium } \\
\text { metasilicate }\end{array}$ & $7.33 \mathrm{Ab}$ & $8.37 \mathrm{Ab}$ & $10.78 \mathrm{Aa}$ \\
\hline & $\begin{array}{l}\text { Potassium } \\
\text { metasilicate }\end{array}$ & $8.08 \mathrm{Ab}$ & $8.11 \mathrm{Ab}$ & $10.50 \mathrm{Aa}$ \\
\hline \multirow[t]{3}{*}{$16 \mathrm{~g} \mathrm{~L}^{-1}$} & $\begin{array}{c}\text { Sodium } \\
\text { metasilicate }\end{array}$ & $8.25 \mathrm{Ab}$ & $9.51 \mathrm{Ab}$ & $11.25 \mathrm{Aa}$ \\
\hline & $\begin{array}{l}\text { Potassium } \\
\text { metasilicate }\end{array}$ & $8.63 \mathrm{Ab}$ & $8.74 \mathrm{Ab}$ & $11.83 \mathrm{Aa}$ \\
\hline & & \multicolumn{3}{|c|}{$\mathrm{CV}(\%)=11.13$} \\
\hline
\end{tabular}

*Means for the Si source not followed by the same uppercase letter in the column and the same lowercase letter on the row were statistically different for soil water regimes in the Tukey test $(\mathrm{p} \leq 0.05)$. WRC: soil water retention capacity. 

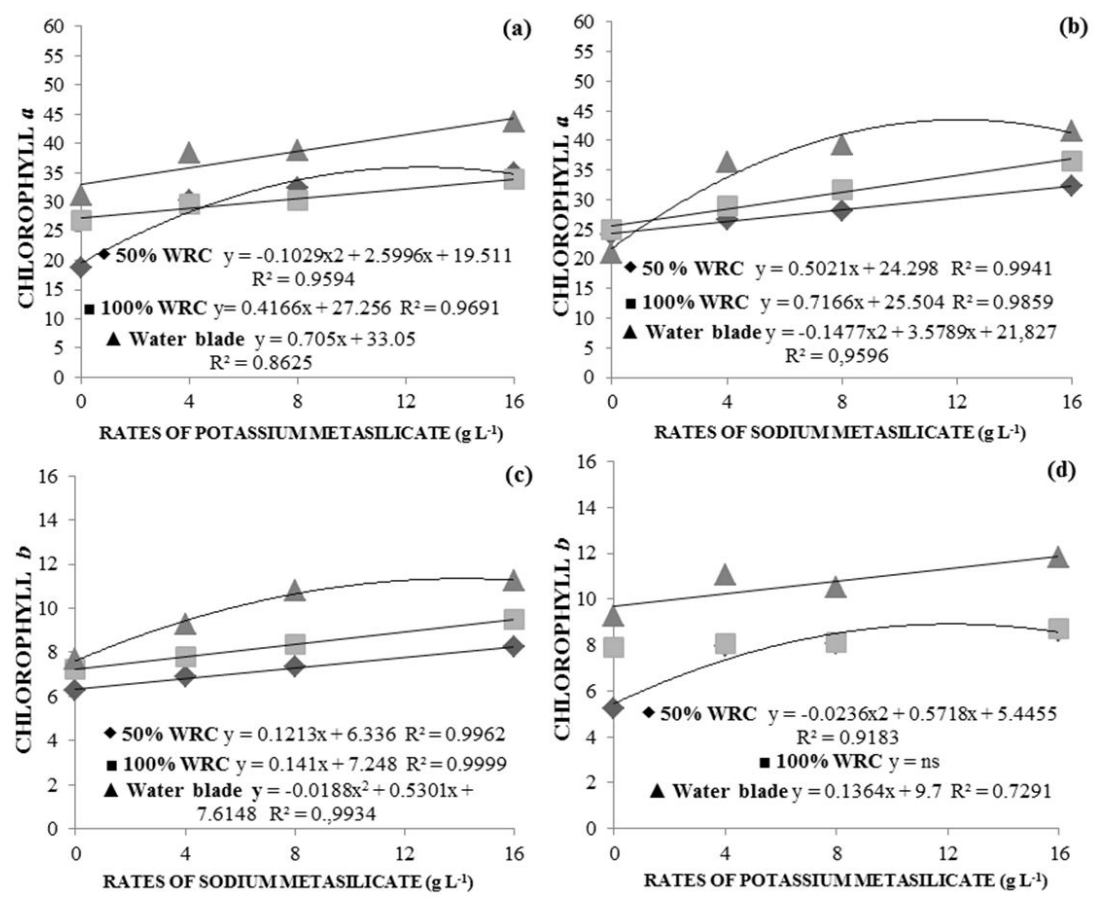

Figure 2. Relationship between the concentrations of chlorophyll $a$ and $b$ in the IRGA 424 RI and Guri INTA CL at means cultivars under different soil water regimes and for different Si rates and sources (sodium metasilicate (b and d) and potassium metasilicate (a and c)). Santa Maria, RS, 2019.

The regression analysis between rates of $\mathrm{Si}$ and chlorophyll $b$ for the sodium metasilicate shows a direct linear relationship with the water regimes of 50 and $100 \%$ WRC and a quadratic relationship under the water blade, peaking at a rate of $12.5 \mathrm{~g} \mathrm{~L}^{-1}$ (Figure 2c). For the potassium metasilicate, chlorophyll $b$ showed a linear increase under the water blade, and a quadratic increase at $50 \% \mathrm{WRC}$, peaking at a rate of $12.4 \mathrm{~g} \mathrm{~L}^{-1}$. At $100 \% \mathrm{WRC}$, there was no significant fit for the polynomial models (Figure 2d).

Note that with the addition of Si the levels of chlorophyll $a$ and $b$ increased under all three water regimes, possibly because Si boosts pigment levels (Gong et al., 2005; Souza, 2008). Furthermore, $\mathrm{Si}$ is related to adjustments in the chloroplast ultrastructure, and is beneficial in maintaining chlorophyll levels (Ahmed et al., 2014). In our study, the pigment level results are related to the production of biomass, since plants exposed to $\mathrm{Si}$ show higher pigment levels with a higher potential to absorb light energy, and therefore produce more biomass.

There is no consensus in the literature on how $\mathrm{Si}$ influences photosynthetic pigment levels. This could be related to the different experimental conditions in individual studies. Shen et al. (2010) reported that applying Si to soybean leaves under water deficiency conditions increased chlorophyll levels in irrigated plants, but this treatment did not alter chlorophyll levels in non-irrigated plants. However, Pei et al. (2010) reported that applying Si to the leaves of wheat increased the chlorophyll level only in plants undergoing water deficiency, not differentiating irrigated plants. In strawberry (Braga et al., 2009) and rice plants (Ávila et al., 2010), supplementing the crop environment with Si did increase chlorophyll levels.

Levels of chlorophyll $a$ were higher than those of chlorophyll $b$. This is usually the case in the majority of plants, since chlorophyll $b$ is an integral part of antenna pigments only, whereas chlorophyll $a$ is an integral part of antenna pigments and photosystem reaction centers (Taiz et al., 2017).

According to Hendry and Price (1993), water deficiency is one of the environmental stresses responsible for leaf pigment reduction, altering the plant's life cycle. According to Marques (2009), this kind of drought stress can reduce net photosynthesis, an effect generally associated with limited synthesis capacity and/or higher degradation of total chlorophylls (chlorophylls $a$ and $b$ ), indicating that under stress plants seem to need alternative routes for dissipating energy in order to avoid photoinhibition and photooxidation problems.

According to Agarie et al. (1998), this increase in chlorophyll levels induced by the application of $\mathrm{Si}$ is associated with the prevention of leaf senescence due to maintained photosynthesis and protection against chlorophyll destruction, especially under high temperature and low humidity conditions. Applying Si to rice under water deficiency conditions increases levels of glycolipids and phospholipids, related to the increase in levels of chlorophyll, and higher stability and improved functioning of the plasma membrane (Wang and Galletta, 1998). 
With regard to shoot lipid peroxidation in the different cultivars under different water regimes (Table 4), the soil water regime induced differences when the plant was not supplemented with $\mathrm{Si}$, with higher lipid peroxidation under water deficiency $(50 \% \mathrm{WRC})$ and at $100 \% \mathrm{WRC}$. In contrast, when the plants were supplemented with Si from different sources and at different rates, there was no significant difference in the shoot lipid peroxidation figures under the three soil water regimes, i.e. the Si may have acted to induce a reduction in lipid peroxidation, regardless of the cultivar and rate applied. This result could be related to POD activity, since Si causes an increase in the activity of this enzyme under water deficiency conditions $(50 \%$ WRC) or at $100 \%$ WRC.

With regard to the cultivars, there was higher lipid peroxidation in Guri INTA CL at 50\% WRC when not supplemented with $\mathrm{Si}$, but when supplemented, there was no significant difference between cultivars (Table 4), indicating that the Si had a very similar effect on both cultivars, possibly because of the fact that they were genetically similar, due to only a restricted group of genetically similar genotypes used extensively as genitors, despite the extensive genetic variability available in germplasm banks (Brondani et al. 2006).

It has been suggested that supplementing plants grown under water deficiency with Si mitigates the negative effects of water deficiency by improving photochemical efficiency and photosynthetic gaseous exchange, as well as activating antioxidant defense capabilities, attenuating lipid peroxidation (Rizwan et al., 2015).

In the regression analysis between rates of $\mathrm{Si}$ and shoot lipid peroxidation, rice cultivars IRGA 424 RI and Guri
INTA CL showed a reduction in lipid peroxidation only under soil water regimes of $50 \% \mathrm{WRC}$, fitting a quadratic polynomial model, with a reduction in lipid peroxidation as rates of sodium metasilicate increased, with respective minimum values at rates of 13 and $12 \mathrm{~g} \mathrm{~L}^{-1}$ (supplementary data). Under soil water regimes of $100 \% \mathrm{WRC}$ and the water blade, there were no significant fits to the polynomial models (supplementary data). In terms of sodium metasilicate rates, lipid peroxidation in the IRGA 424 RI cultivar at 50\% WRC was reduced quadratically, with the trough at a rate of $11 \mathrm{~g} \mathrm{~L}^{-1}$. At $100 \% \mathrm{WRC}$ and under the water blade, there were no significant fits to the polynomial models. In contrast, the Guri INTA CL cultivar at $100 \% \mathrm{WRC}$, supplemented with Si (sodium metasilicate), exhibited negative linear behavior, with lipid peroxidation falling as rates of sodium metasilicate increased. At $50 \%$ WRC and under the water blade there were no significant fits to the polynomial models (supplementary data).

These results show that the presence of Si brought about a significant reduction in shoot lipid peroxidation in rice plants undergoing water deficiency. This could mean that the harm caused by ROS under water deficiency was attenuated by adding $\mathrm{Si}$, in part due to increased POD and SOD activity. It is possible that applying Si might effectively increase the rice plant's capacity to defend against oxidative stress induced by drought stress (supplementary data). Shi et al. (2005) reported that Si brought about a drop in membrane lipid peroxidation by stimulating enzymatic and non-enzymatic antioxidants.

Measurements of POD enzyme activity under the different soil water regimes indicated that enzyme activity was higher at $50 \%$ WRC. Higher rates of $\mathrm{Si}\left(8.0\right.$ and $\left.16 \mathrm{~g} \mathrm{~L}^{-1}\right)$

Table 4. Means for rice plant shoot lipid peroxidation for different Si rates and different cultivars for the water regime factor. Santa Maria, RS, 2019.

\begin{tabular}{|c|c|c|c|c|c|}
\hline \multirow{2}{*}{ RATES OF Si } & \multirow{2}{*}{$\begin{array}{c}\text { SOURCES } \\
\text { OF Si }\end{array}$} & \multirow{2}{*}{ CULTIVAR } & \multicolumn{3}{|c|}{ WATER SOIL CONDITIONS } \\
\hline & & & $50 \%$ WRC & $100 \%$ WRC & Water blade \\
\hline \multirow[t]{4}{*}{$0 \mathrm{~g} \mathrm{~L}^{-1}$} & \multirow{2}{*}{$\begin{array}{l}\text { Potassium } \\
\text { metasilicate }\end{array}$} & Guri INTA CL & $0.0700 \mathrm{Aa}^{*}$ & $0.010 \mathrm{Bb}$ & $0.0100 \mathrm{Ab}$ \\
\hline & & IRGA 424RI & $0.0500 \mathrm{Ba}$ & $0.040 \mathrm{Aa}$ & $0.0100 \mathrm{Ab}$ \\
\hline & \multirow{2}{*}{$\begin{array}{c}\text { Sodium } \\
\text { metasilicate }\end{array}$} & Guri INTA CL & $0.0170 \mathrm{Ba}$ & $0.200 \mathrm{Ab}$ & $0.0130 \mathrm{Ab}$ \\
\hline & & IRGA 424RI & $0.0400 \mathrm{Aa}$ & $0.0170 \mathrm{Aa}$ & $0.0170 \mathrm{Aa}$ \\
\hline \multirow[t]{4}{*}{$4.0 \mathrm{~g} \mathrm{~L}^{-1}$} & \multirow{2}{*}{$\begin{array}{l}\text { Potassium } \\
\text { metasilicate }\end{array}$} & Guri INTA CL & $0.0200 \mathrm{Aa}$ & $0.0100 \mathrm{Aa}$ & $0.0100 \mathrm{Aa}$ \\
\hline & & IRGA 424RI & $0.0100 \mathrm{Aa}$ & $0.0130 \mathrm{Aa}$ & $0.0100 \mathrm{Aa}$ \\
\hline & \multirow{2}{*}{$\begin{array}{c}\text { Sodium } \\
\text { metasilicate }\end{array}$} & Guri INTA CL & $0.0100 \mathrm{Aa}$ & $0.0100 \mathrm{Aa}$ & $0.0130 \mathrm{Aa}$ \\
\hline & & IRGA 424RI & $0.0033 \mathrm{Aa}$ & $0.0100 \mathrm{Aa}$ & $0.0100 \mathrm{Aa}$ \\
\hline \multirow[t]{4}{*}{$8.0 \mathrm{~g} \mathrm{~L}^{-1}$} & \multirow{2}{*}{$\begin{array}{l}\text { Potassium } \\
\text { metasilicate }\end{array}$} & Guri INTA CL & $0.0100 \mathrm{Aa}$ & $0.0100 \mathrm{Aa}$ & $0.0133 \mathrm{Aa}$ \\
\hline & & IRGA 424RI & $0.0100 \mathrm{Aa}$ & $0.1000 \mathrm{Aa}$ & $0.0067 \mathrm{Aa}$ \\
\hline & \multirow{2}{*}{$\begin{array}{c}\text { Sodium } \\
\text { metasilicate }\end{array}$} & Guri INTA CL & $0.0033 \mathrm{Aa}$ & $0.0070 \mathrm{Aa}$ & $0.0100 \mathrm{Aa}$ \\
\hline & & IRGA 424RI & $0.0000 \mathrm{Aa}$ & $0.0100 \mathrm{Aa}$ & $0.0067 \mathrm{Aa}$ \\
\hline \multirow[t]{5}{*}{$16 \mathrm{~g} \mathrm{~L}^{-1}$} & \multirow{2}{*}{$\begin{array}{l}\text { Potassium } \\
\text { metasilicate }\end{array}$} & Guri INTA CL & $0.0067 \mathrm{Aa}$ & $0.0066 \mathrm{Aa}$ & $0.0067 \mathrm{Aa}$ \\
\hline & & IRGA 424RI & $0.0033 \mathrm{Aa}$ & $0.0066 \mathrm{Aa}$ & $0.0067 \mathrm{Aa}$ \\
\hline & \multirow{3}{*}{$\begin{array}{c}\text { Sodium } \\
\text { metasilicate }\end{array}$} & Guri INTA CL & $0.0033 \mathrm{Aa}$ & $0.0030 \mathrm{Aa}$ & $0.0030 \mathrm{Aa}$ \\
\hline & & IRGA 424RI & $0.0000 \mathrm{Aa}$ & $0.0067 \mathrm{Aa}$ & $0.0070 \mathrm{Aa}$ \\
\hline & & & CV & 75.42 & \\
\hline
\end{tabular}

* Means not followed by the same uppercase letter in the column were statistically different between cultivars and the same lowercase letter on the rows for soil water regimes in the Tukey test $(\mathrm{p} \leq 0.05)$. WRC: soil water retention capacity. 
Table 5. Means for guaiacol peroxidase (POD) enzyme activity in the rice plant at different Si rates for the water regime factor. Santa Maria, RS, 2019.

\begin{tabular}{cccc}
\hline \multirow{2}{*}{ RATES OF Si } & \multicolumn{3}{c}{ WATER SOIL CONDITIONS } \\
\cline { 2 - 4 } & $\mathbf{5 0 \% \text { WRC }}$ & $\mathbf{1 0 0 \%}$ WRC & Water blade \\
\hline $0 \mathrm{~g} \mathrm{~L}^{-1}$ & $66.67 \mathrm{a}^{*}$ & $76.69 \mathrm{a}$ & $67.32 \mathrm{a}$ \\
$4.0 \mathrm{~g} \mathrm{~L}^{-1}$ & $81.49 \mathrm{a}$ & $83.20 \mathrm{a}$ & $74.57 \mathrm{a}$ \\
$8.0 \mathrm{~g} \mathrm{~L}^{-1}$ & $98.61 \mathrm{a}$ & $104.74 \mathrm{a}$ & $78.76 \mathrm{~b}$ \\
$16 \mathrm{~g} \mathrm{~L}^{-1}$ & $112.68 \mathrm{a}$ & $120.86 \mathrm{a}$ & $82.21 \mathrm{~b}$ \\
\hline
\end{tabular}

*Means not followed by the same letter on the row were statistically different for differing soil water regimes in the Tukey test $(\mathrm{p} \leq 0.05)$. WRC: soil water retention capacity.
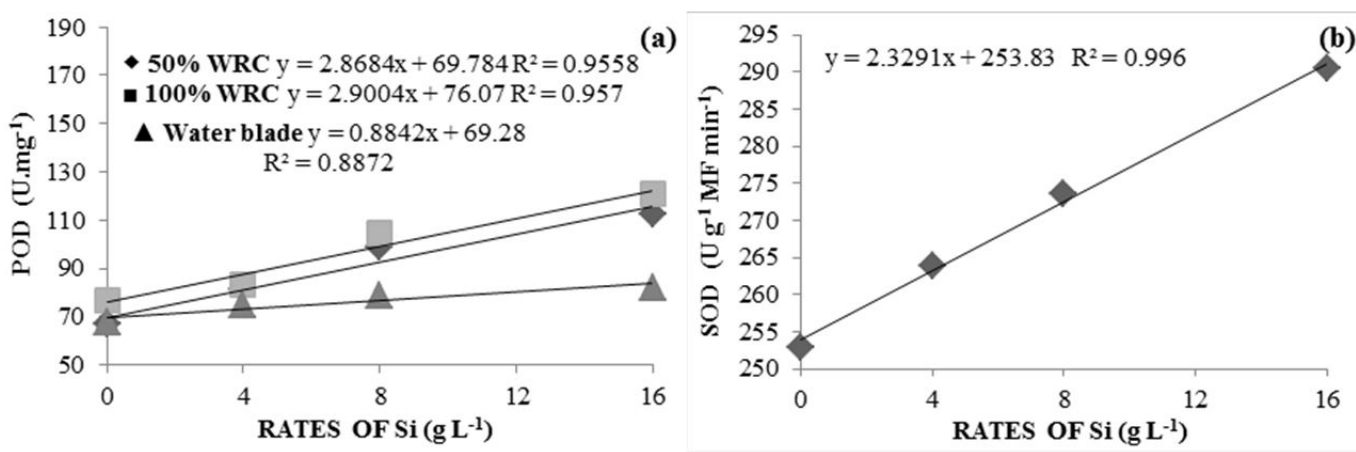

Figure 3. Relationship between guaiacol peroxidase (POD) enzymatic activity in the shoots of rice plants under different soil water regimes: 50 and 100\% WRC and water blade at different Si rates (means for sodium metasilicate and potassium metasilicate sources and IRGA 424 RI and Guri INTA CL cultivars) (a). Superoxide dismutase (SOD) enzymatic activity at different Si rates (means for sodium metasilicate and potassium metasilicate sources IRGA 424 RI and Guri INTA CL cultivars and different soil water regimes: 50 and 100\% WRC and water blade) (b). Santa Maria, RS, 2019.

increased POD activity under drought stress (50\% WRC) and at $100 \%$ WRC compared to plants grown under the water blade (Table 5). This suggests that the increase in POD enzyme activity induced by adding Si could protect plant tissues under drought stress from oxidative damage, which could contribute significantly to increasing drought tolerance.

The regression analysis between rates of Si and POD activity showed that supplementing with $\mathrm{Si}$ at the highest rate $\left(16 \mathrm{~g} \mathrm{~L}^{-1}\right)$ increased respective enzyme activity by 68 , 57 and $22 \%$ under the three soil water regimes, compared to plants not supplemented with Si (Figure 3a). It is important to point out that $\mathrm{Si}$ has the potential to activate the antioxidant system, regardless of the presence of the stress factor. The results corroborate those found by Verma and Dubey (2003) who observed an increase in POD activity in rice when subjected to stress conditions.

Taking into account the mean enzymatic activity of SOD, the regression analysis shows a linear increase in enzyme activity as rates of $\mathrm{Si}$ increase, with an increment of $15 \%$ at the highest rate $\left(16 \mathrm{~g} \mathrm{~L}^{-1}\right)$ compared to plants not supplemented with $\mathrm{Si}\left(0 \mathrm{~g} \mathrm{~L}^{-1}\right)$. This can be positive if the objective is to mitigate the effect of stress that involves the production of ROS in the rice crop (Figure $3 b$ ). The increase in antioxidant enzyme activity in the presence of $\mathrm{Si}$ indicated that $\mathrm{Si}$ could be involved in increasing the expression of genes related to the production and activation of antioxidant enzymes (Biju et al., 2018).

The increase in SOD activity under stress conditions could result in higher efficiency in the elimination of ROS (Wang et al., 2005). These ROS cause oxidative stress, which in the final analysis results in cell damage that could kill the plant (Sfalcin, 2009). Schmidt et al. (1999) reported that $\mathrm{Si}$ increases antioxidant enzyme levels under low humidity conditions.

\section{Conclusion}

Chlorophyll $\mathrm{a}$ and $\mathrm{b}$ and shoot and root dry weight increased at higher rates of Si under the three soil water regimes, in both sources.

Shoot lipid peroxidation was greater when the plants was not supplemented with $\mathrm{Si}$, under water deficiency $(50 \%$ WRC) and at $100 \%$ WRC. In contrast, when the plants were supplemented with Si from different sources and at different rates, there was no significant difference in the shoot lipid peroxidation figures under the three soil water regimes, i.e. the Si have acted to induce a reduction in lipid peroxidation, regardless of the cultivar and rate applied. This result related to POD activity, since Si caused an increase in the activity of this enzyme under drought stress conditions $(50 \% \mathrm{WRC})$ or at $100 \%$ WRC. Furthermore, 
the SOD enzymatic activity increased at higher rates of Si $\left(16 \mathrm{gL}^{-1}\right)$.

The leaf area increased in the three soil water regimes associated with a higher dose $\left(16 \mathrm{~g} \mathrm{~L}^{-1}\right)$ of $\mathrm{Si}$, demonstrating its beneficial action, even in regimes of drought stress (50\% CRA).

Therefore, Si did indeed attenuate water deficiency stress in rice plants emerging from seeds treated with dietholate.

\section{Acknowledgements}

This research was financially supported by Coordenação de Aperfeiçoamento de Pessoal de Nível Superior (CAPES).

\section{References}

AGARIE, S., HANAOKA, N., UENO, O., MIYAZAKI, A., KUBOTA, F., AGATA, W. and KAUFMAN, P.B., 1998. Effects of silicon on tolerance to water deficit and heat stress in rice plants (Oryza sativa L.), monitored by electrolyte leakage. Plant Production Science, vol. 1, no. 1, pp. 96-103. http://dx.doi. org/10.1626/pps.1.96.

AHMED, M., ASIF, M. and HASSAN, F.U., 2014. Augmenting drought tolerance in sorghum by silicon nutrition. Acta Physiologiae Plantarum, vol. 36, no. 2, pp. 473-483. http://dx.doi.org/10.1007/ s11738-013-1427-2.

ANTIGUA, G., COLON, C. and GARCIA, J., 1990. Utlizacion del herbicida Arrozan en el control de malezas del arroz en Cuba. Ciencia y Tecnica en la Agricultura - Arroz, vol. 13, no. 1-2, pp. 135-144.

ASHRAF, M. and FOOLAD, M., 2007. Roles of glycine betaine and proline in improving plant abiotic stress resistance. Environmental and Experimental Botany, vol. 59, no. 2, pp. 206-216. http:// dx.doi.org/10.1016/j.envexpbot.2005.12.006.

ÁVILA, F.W., BALIZA, D.P., FAQUIN, V., ARAÚJO, J.L. and RAMOS, S.J., 2010. Interação entre Si e nitrogênio em arroz cultivado sob solução nutritiva. Ciência Agronômica, vol. 41, no. 2, pp. 184-190. http://dx.doi.org/10.1590/S1806-66902010000200003.

BIJU, S., FUENTES, S. and GUPTA, D., 2018. The use of infrared thermal imaging as a non-destructive screening tool for identifying drought-tolerant lentil genotypes. Plant Physiology and Biochemistry, vol. 127, pp. 11-24. http://dx.doi.org/10.1016/j. plaphy.2018.03.005. PMid:29544209.

BOYER, J.S., 1982. Plant productivity and environment. Science, vol. 218, no. 4571, pp. 443-448. http://dx.doi.org/10.1126/ science.218.4571.443. PMid:17808529.

BRAGA, F.T., NUNES, C.F., FAVERO, A.C., PASQUAL, M., CARVALHO, J.G. and CASTRO, E.M., 2009. Características anatômicas de mudas de morangueiro micropropagadas com diferentes fontes de Si. Pesquisa Agropecuária Brasileira, vol. 44, no. 2, pp. 128-132. http://dx.doi.org/10.1590/S0100204X2009000200003.

BRONDANI, C., BORBA, T.C.O., RANGEL, P.H.N. and BRONDANI, R.P.V., 2006. Determination of genetic variability of traditional varieties of Brazilian rice using microsatellite markers. Genetics and Molecular Biology, vol. 29, no. 4, pp. 676-684. http://dx.doi.org/10.1590/S1415-47572006000400017.
COMPANHIA NASCIONAL DE ABASTECIMENTO - CONAB, 2019. Acompanhamento da Safra Brasileira Grãos, v. 6 Safra 2018/19 - Sexto levantamento. Brasília: CONAB, pp. 1-6.

CROOKS, R. and PRENTICE, P., 2017. Extensive investigation into field based responses to a silica fertilizer. Silicon, vol. 9, pp. 301-304. https://doi.org/10.1007/s12633-015-9379-3.

EL-MOSHATY, F.I.B., PIKE, S.M., NOVACKY, A.J. and SEHGAL, O.P., 1993. Lipid peroxidation and superoxide productions in cowpea (Vigna unguiculata) leaves infected with tobacco rings virus or southern bean mosaic virus. Journal of Physiological and Molecular Plant Pathology, vol. 43, no. 2, pp. 109-119. http:// dx.doi.org/10.1006/pmpp.1993.1044.

ENEJI, A.E., INANAGA, S., MURANAKA, S., LI, J., HATTORI, T., AN, P. and TSUJI, W., 2008. Growth and nutrient use in four grasses under drought stress as mediated by silicon fertilizers. Journal of Plant Nutrition, vol. 31, no. 2, pp. 355-365. http:// dx.doi.org/10.1080/01904160801894913.

EPSTEIN, E., 1999. Silicon. Annual Review of Plant Biology, vol. 50, no. 1, pp. 641-664. http://dx.doi.org/10.1146/annurev. arplant.50.1.641. PMid:15012222.

ETESAMI, H. and JEONG, B.R., 2017. Review and future prospects on the action mechanisms in alleviating biotic and abiotic stresses in plants. Ecotoxicology and Environmental Safety, vol. 147, pp. 881-896. http://dx.doi.org/10.1016/j.ecoenv.2017.09.063. PMid:28968941.

FARIA JÚNIOR, L.A., CARVALHO, J.G., PINHO, P.J., BASTOS, A.R.R. and FERREIRA, E.V.O., 2009. Produção de matéria seca, teor e acúmulo de $\mathrm{Si}$ em cultivares de arroz sob doses de $\mathrm{Si}$. Ciência e Agrotecnologia, vol. 33, no. 4, pp. 1034-1040. http:// dx.doi.org/10.1590/S1413-70542009000400013.

FERHATOGLU, Y., AVDIUSHKO, S. and BARRET, M., 2005. The basic for safening of clomazone by phorate insecticide in cotton and inhibitors of cytochrome P450s. Pesticide Biochemistry and Physiology, vol. 81, no. 1, pp. 59-70. http://dx.doi.org/10.1016/j. pestbp.2004.09.002.

FERREIRA, D.F., 2014. Sisvar: A guide for its bootstrap procedures in multiple comparisons. Ciência e Agrotecnologia, vol. 38, no. 2, pp. 109-112. http://dx.doi.org/10.1590/S1413-70542014000200001.

GIANNOPOLITIS, C.N. and RIES, S.K., 1977. Purification and quantitative relationship with water-soluble protein in seedlings. Plant physiology, vol. 59, no. 2, pp. 315-318. http://dx.doi. org/10.1104/pp.59.2.315. PMid:16659840.

GONG, H., ZHU, X., CHEN, K., WANG, S. and ZHANG, C., 2005. Silicon alleviates oxidative damage of wheat plants in potsunder drought. Plant Science, vol. 169, no. 2, pp. 313-321. http://dx.doi.org/10.1016/j.plantsci.2005.02.023.

HABIBI, G., 2014. Silicon supplementation improves drought tolerance in canola plants. Russian Journal of Plant Physiology: a Comprehensive Russian Journal on Modern Phytophysiology, vol. 61, no. 6, pp. 784-791. http://dx.doi.org/10.1134/S1021443714060077.

HATTORI, T., INANAGA, S., ARAKI, H., NA, P., MORITA, S., LUXOVÁ, M. and LUX, A., 2005. Application of silicon enhanced drought tolerance in Sorghum bicolor. Physiologia Plantarum, vol. 123, no. 4, pp. 459-466. http://dx.doi.org/10.1111/j.13993054.2005.00481.x.

HENDRY, G.A.F. and PRICE, A.H. 1993. Stress indicators: chlorophylls and carotenoids. In: G.A.F. HENDRY and J.P. GRIME, eds. Methods in comparative plant ecology. London: 
Chapman and Hall, pp. 148-152. http://dx.doi.org/10.1007/97894-011-1494-3.

INOUE, M.H., ARAÚJO, T.D.C., MENDES, K.F., BEN, R. and CONCIANI, P.A., 2012. Eficiência do dietholate e bioestimulantes isolados e associados no tratamento de sementes de algodoeiro adensado com clomazone aplicado em pré-emergência. Revista de Ciências Agro-ambientais, vol. 10, no. 2, pp. 163-172.

ISMAIL, A.M., JOHNSON, D.E., ELLA, E.S., VERGARA, G.V., BALTAZAR, A.M., 2012. Adaptation to flooding during emergence and seedling growth in rice and weeds, and implications for crop establishment. AoB PLANTS, v. 2012, pp. 1-18. http:// dx.doi.org/10.1093/aobpla/pls019

KARAM, D., CARNEIRO, A.A., ALBERT, L.H., CRUZ, M.B., COSTA, G.T. and MAGALHÃES, P.C., 2003. Seletividade da cultura do milho ao herbicida clomazone por meio do uso de dietholate. Revista Brasileira de Milho e Sorgo, vol. 2, no. 1, pp. 72-79. http://dx.doi.org/10.18512/1980-6477/rbms.v2n1p72-79.

KIM, Y.-H., KHAN, A.L., SHINWARI, Z.K., KIM, D.-H., WAQAS, M., KAMRAN, M. and LEE, I.-J., 2012. Silicon treatment to rice (Oryza sativa L. cv. 'Gopumbyeo') plants during different growth periods and its effects on growth and grain yield. Pakistan Journal of Botany, vol. 44, pp. 891-897.

LEE, S.K., SOHN, E.Y., HAMAYUN, M., YOON, J.Y. and LEE, I.J., 2010. Effect of silicon on growth and salinity stress of soybean plant grown under hydroponic system. Agroforestry Systems, vol. 80, no. 3, pp. 333-340. http://dx.doi.org/10.1007/ s10457-010-9299-6.

LIANG, Y., SUN, W., ZHU, Y.G. and CHRISTIE, P., 2007. Mechanisms of silicon mediated alleviation of abiotic stresses in higher plants: a review. Environmental Pollution, vol. 147, no. 2, pp. 422-428. http://dx.doi.org/10.1016/j.envpol.2006.06.008. PMid:16996179.

LIMA, M.A., CASTRO, V.F., VIDAL, J.B. and FILHO, J.E., 2011. Aplicação de Si em milho e feijão-de corda sob estresse salino. Ciência Agronômica, vol. 42, no. 2, pp. 398-403. http:// dx.doi.org/10.1590/S1806-66902011000200019.

MA, J.F., 2004. Role of silicon in enhancing the resistance of plants to biotic and abiotic stresses. Soil Science and Plant Nutrition, vol. 50, no. 1, pp. 11-18. http://dx.doi.org/10.1080/00 380768.2004 .10408447$.

MA, J.F., YAMAJI, N., MITANI, N., TAMAI, K., KONISHI, S., FUJIWARA, T., KATSUHARA, M. and YANO, M., 2007. An efflux transporter of silicon in rice. Nature, vol. 448, no. 7150, pp. 209-212. http://dx.doi.org/10.1038/nature05964. PMid:17625566.

MANIVANNAN, A. and AHN, Y.-K., 2017. Silicon Regulates Potential Genes Involved in Major Physiological Processes in Plants to Combat Stress. Frontiers of Plant Science, vol. 8, pp. 1346. http://dx.doi.org/10.3389/fpls.2017.01346. PMid:28824681.

MARQUES, D.J., 2009. Estresse mineral induzido por fertilizantes potássicos em plantas de berinjela (Solanum melogena L.) e seu efeito sobre parâmetros agronômicos e metabólicos. Faculdade de Ciências Agronômicas da UNESP, Botucatu Dissertação de Mestrado em Agronomia/Horticultura.

MAUAD, M., CRUSCIOL, C.A.C. and FILHO, H.G., 2011. Produção de massa seca e nutrição de cultivares de arroz de terras altas sob condição de déficit hídrico e adubação silicatada. Semina, vol. 32, no. 3, pp. 939-948. http://dx.doi.org/10.5433/16790359.2011v32n3p939.
MUNEER, S., PARK, Y.G., MANIVANNAN, A., SOUNDARARAJAN, P. and JEONG, B.R., 2014. Physiological and proteomic analysis in chloroplasts of Solanum lycopersicum L. under silicon efficiency and salinity stress. International Journal of Molecular Sciences, vol. 15 , no. 12 , pp. 21803-21824. http://dx.doi.org/10.3390/ ijms151221803. PMid:25431925.

PATI, S., PAL, B., BADOLE, S., HAZRA, G.C. and MANDAL, B., 2016. Effect of silicon fertilization on growth, yield, and nutrient uptake of rice. Communications in Soil Science and Plant Analysis, vol. 47, no. 3, pp. 284-290. http://dx.doi.org/10. 1080/00103624.2015.1122797.

PEI, Z.F., MING, D.F., LIU, D., WAN, G.L., GENG, X.X., GONG, H.J. and ZHOU, W.J., 2010. Silicon improves the tolerance to water deficit stress induced by polyethylene glycol in wheat (Triticum aestivum L.) seedlings. Journal of Plant Growth Regulation, vol. 29, no. 1, pp. 106-115. http://dx.doi.org/10.1007/ s00344-009-9120-9.

RIZWAN, M., ALI, S., IBRAHIM, M., FARID, M., ADREES, M., BHARWANA, S.A., ZIA-UR-REHMAN, M., QAYYUM, M.F. and ABBAS, F., 2015. Mechanisms of silicon-mediated alleviation of drought and salt stress in plants: a review. Environmental Science and Pollution Research International, vol. 22, no. 20, pp. 15416-15431. http://dx.doi.org/10.1007/s11356-015-5305-x. PMid:26335528.

SANCHOTENE, D.M., KRUSE, N.D., AVILA, L.A., MACHADO, S.L.O., NICOLODI, G.A. and DORNELLES, S.H.B., 2010. Efeito do protetor dietholate na seletividade de clomazone em cultivares de arroz irrigado. Planta Daninha, vol. 28 , no. 2, pp. 339-346. http://dx.doi.org/10.1590/S010083582010000200013

SÁVIO, F.L., SILVA, G.C., TEIXEIRA, I.R. and BORÉM, A., 2011. Produção de biomassa e conteúdo de silício em gramíneas forrageiras sob diferentes fontes de silicato. Semina: Ciências Agrárias, vol. 32, no. 1, pp. 103-110. http://dx.doi.org/10.5433/16790359.2011v32n1p103.

SCHMIDT, R.E., ZHANG, X. and CHALMERS, D.R., 1999. Response of photosynthesis and superoxide dimutase to silica applied to creeping bentgrass grown under two fertility levels. Journal of Plant Nutrition, vol. 22, no. 11, pp. 1763-1773. http:// dx.doi.org/10.1080/01904169909365752.

SFALCIN, R.A., 2009. Avaliação de parâmetros fisiológicos e bioquímicos em berinjela (Solanum melongena L.) cultivada sob diferentes potenciais de água no solo. Botucatu: Universidade Estadual Paulista. Dissertação de Mestrado em Agronomia/ Energia na Agricultura)

SHARMA, P. and DUBEY, R.S., 2005. Modulation of nitrate reductase activity in rice seedlings under aluminium toxicity and drought stress: role of osmolytes as enzyme protectant. Journal of Plant Physiology, vol. 162, no. 8, pp. 854-862. http://dx.doi. org/10.1016/j.jplph.2004.09.011. PMid:16146311.

SHEN, X., ZHOU, Y., DUAN, L., LI, Z., ENEJI, A.E. and LI, J., 2010. Silicon effects on photosynthesis and antioxidant parameters of soybean seedlings under drought and ultraviolet-B radiation. Journal of Plant Physiology, vol. 167, no. 15, pp. 1248-1252. http://dx.doi.org/10.1016/j.jplph.2010.04.011. PMid:20713250.

SHI, Q.H., BAO, Z., ZHU, Z., HE, Y., QIAN, Q. and YU, J., 2005. Silicon mediated alleviation of Mn toxicity in Cucumis sativus in relation to activities of superoxide dismutase and ascorbate peroxidase. Phytochemistry, vol. 41, no. 66, pp. 
1551-1559. http://dx.doi.org/10.1016/j.phytochem.2005.05.006. PMid:15963540.

SILVA, K.S., TABALDI, L.A., ROSSATO, L.V., BASILIO, V.B., CAVICHIOLI, B.M. and MACHADO, S.L.O., 2019. Contents of pigments and activity of antioxidant enzymes in rice plants pre-treated with sodium nitroprusside and exposed to clomazone. Planta Daninha, vol. 37, pp. 1-10. http://dx.doi.org/10.1590/ s0100-83582019370100032.

SOUNDARARAJAN, P., SIVANESAN, I., JANA, S. and JEONG, B.R., 2014. Influence of silicon supplementation on the growth and tolerance to high temperature in Salvia splendens. Horticulture, Environment and Biotechnology, vol. 55, no. 4, pp. 271-279. http://dx.doi.org/10.1007/s13580-014-0023-8.

SOUZA, J.V. 2008. Aplicação de silicato de potássio via foliar no milho: fotossintese, crescimento e produtividade. Uberlândia: Universidade Federal de Uberlândia, 33 p. Monografia.

SPATT, L.L., 2018. Desempenho fotossintético e eficiência de herbicidas em Urochloa plantaginea (Poaceae) submetidas às diferentes condições hídricas do solo e doses de nitrogênio. Universidade Federal de Santa Maria, Santa Maria, 15 p. Dissertação de Mestrado em Agrobiologia.

TAIZ, L., ZEIGER, E., MOLLER, I.M. and MURPH, A., 2017. Fisiologia e desenvolvimento vegetal. $6^{\mathrm{a}}$ ed. Porto Alegre: Artmed Editora S.A., 120p.

TRIPATHI, D.K., SINGH, V.P., GANGWAR, S., PRASAD, S.M., MAURYA, J.N. and CHAUHAN, D.K., 2014. Role of silicon in enrichment of plant nutrients and protection from biotic and abiotic stresses. In: P. AHMAD, M.R. WANI, M.M. AZOOZ and L.S.P. TRAN, eds. Improvement of crops in the era of climatic changes. New York, NY: Springer, pp. 39-56.

VERMA, S. and DUBEY, R.S., 2003. Lead toxicity induces lipid peroxidation and alters the activities of antioxidant enzymes in growing rice plants. Plant Science, vol. 164, no. 4, pp. 645-655. http://dx.doi.org/10.1016/S0168-9452(03)00022-0.
WANG, F.-Z., WANG, Q.-B., KWON, S.-Y., KWAK, S.-S. and SU, W.-A., 2005. Enhanced drought tolerance of transgenic rice plant s expressing a pea manganese superoxide dismutase. Journal of Plant Physiology, Stuttgart, vol. 162, no. 4, pp. 465-472. http:// dx.doi.org/10.1016/j.jplph.2004.09.009.

WANG, S.Y. and GALLETTA, G.J., 1998. Foliar application of potassium silicate induces metabolic changes in strawberry plants. Journal of Plant Nutrition, vol. 21, no. 1, pp. 157-167. http://dx.doi.org/10.1080/01904169809365390.

WOODRUFF, D.R. and MEINZER, F.C., 2011. Size-dependent changes in biophysical control of tree growth: The role of turgor. In: F.C. MEINZER, B. LACHENBRUCH and T.E. DAWSON, eds. Size-and age-related changes in tree structure and function . Netherlands: Springer, pp. 363-384. http://dx.doi.org/10.1007/97894-007-1242-3_14.

YUN, M.S., YOGO, Y., MIURA, R., YAMASUE, Y. and FISCHER, A.J., 2005. Cytochrome P-450 monooxygenase activity in herbicide-resistant and - susceptible late watergrass (Echinochloa phyllopogon). Pesticide Biochemistry and Physiology, vol. 83, no. 2-3, pp. 107-114. http://dx.doi.org/10.1016/j.pestbp.2005.04.002.

ZERAIK, A.E., SOUZA, F.S., FATIBELLO-FILHO, O. and LEITE, O.D., 2008. Desenvolvimento de um spot test para o monitoramento da atividade da peroxidase em um procedimento de purificação. Quimica Nova, vol. 31, no. 4, pp. 731-734. http:// dx.doi.org/10.1590/S0100-40422008000400003.

ZHANG, Q., LIU, J., LU, H., ZHAO, S., WANG, W., DU, J. and YAN, C., 2015. Effects of silicon on growth, root anatomy, radial oxygen loss (ROL) and Fe/Mn plaque of Aegiceras corniculatum (L.) Blanco seedlings exposed to cadmium. Environmental Nanotechnology, Monitoring \& Management, vol. 4, pp. 6-11. http://dx.doi.org/10.1016/j.enmm.2015.04.001.

ZHU, Z., WEI, G., LI, J., QIAN, Q. and YU, J., 2004. Silicon alleviates salt stress and increases antioxidant enzymes activity in leaves of salt-stressed cucumber (Cucumis sativus L.). Plant Science, vol. 167, no. 3, pp. 527-533. http://dx.doi.org/10.1016/j. plantsci.2004.04.020. 


\section{Supplementary Material}

Supplementary material accompanies this paper.

Suppl. data. Relationship between concentration of shoot and root dry weight and shoot lipid peroxidation for the IRGA 424 RI and Guri INTA CL cultivars under different soil water regimes, Si rates and Si sources. Santa Maria, RS, 2019.

This material is available as part of the online article from http:/www.scielo.br/bjb 